\title{
Trace elements mobility in soils from the hydrothermal area of Nisyros (Greece)
}

\author{
Kyriaki Daskalopoulou ${ }^{1}$, Sergio Calabrese ${ }^{2 *}$, Silvia Milazzo ${ }^{2}$, Lorenzo Brusca ${ }^{3}$, \\ Sergio Bellomo ${ }^{3}$, Walter D' Alessandro ${ }^{3}$, Konstantinos Kyriakopoulos ${ }^{1}$, Franco \\ TASSI $^{4}$, FRANCESCO PARELLO ${ }^{2}$ \\ 1 Department of Geology and Geoenvironment, University of Athens, Greece, 2 Dipartimento \\ di Scienze della Terra e del Mare, University of Palermo, Italy, 3 Istituto Nazionale di Geofisica \\ e Vulcanologia Palermo, Italy, 4 Department of Earth Sciences, University of Florence, Italy \\ *sergio.calabrese@gmail.com
}

\begin{abstract}
Nisyros Island, Greece, is a stratovolcano known for its intense hydrothermal activity. On June 2013, during a multidisciplinary field campaign, soil samples were collected in the caldera area to determinate the main mineralogical assemblages and to investigate the distribution of trace element concentrations and the possible relationship to the contribution of fluids of deep origin. Soil samples were analysed with XRD and for the chemical composition of their leachable (deionized water) and pseudo total (microwave digestion) fraction both for major and trace elements. The results allow to divide the samples in 2 groups: Lakki Plain and Stefanos Crater. The latter, where a fumarolic area is located, shows a mineralogical assemblage dominated by phases typical of hydrothermal alteration. Their very low $\mathrm{pH}$ values $(1.9$ - 3.4) show the strong impact of fumarolic gases which are probably also the cause of strong enrichments in these soils of highly volatile elements like S, As, Se, Bi, Sb, Tl and Te.
\end{abstract}

\section{INTRODUCTION}

$\mathrm{T}$ race elements are considered to be the chemical elements whose concentration is less than $1000 \mathrm{ppm}$ of rock's composition. In soils, they originate from natural and anthropogenic sources. Consequently, their concentrations can vary considerably. The trace element loading in soil is a function of the parent material plus subsequent atmospheric or water-borne deposition. High concentrations of trace elements in soil can affect the soil's fertility and may represent an ecological and human health risk if they enter the food chain or leach into receiving waters. However, the impact of trace metals on soil and the surrounding environment often cannot be predicted simply by measuring the total concentration, since only the soluble and mobile fraction has the potential to leach or to be taken up by plants and enter the food chain [Robinson et al., 2005]. The mobility, solubility and bioaccumulation of trace elements depend on various factors, as well as their properties. A strongly acidic environment can favour mobility. Such conditions can be the result of natural processes, such as magmatic/geothermal degassing or oxidation of sulfide minerals. Natural processes generating metal-rich acid waters have highlighted the importance of metal-sulfate minerals, forming upon 
ANNALS OF GEOPHYSICS, Fast Track 2, 2014

evaporation, oxidation and neutralization processes [Alpers et al., 2000]. Metal sulfate salts are common around active crater lakes, fumaroles and acid hot springs [Delmelle and Bernard, 2000; Fulignati et al., 2006; Nordstrom et al., 2009]. In these environments, $\mathrm{H}_{2} \mathrm{~S}$ is oxidized to elemental $S$, which accumulates and is further, oxidized to form sulfuric acid [Jambor et al., 2000]. The acid reacts with the surrounding bedrock, leading to the formation of a variety of metal-sulfate minerals. Some of these minerals are highly soluble and store metals and acidity only temporarily, whereas others are insoluble and improve water quality by removing metals from solutions. Sometimes geothermal/volcanic activity is, therefore, responsible for elevated fluxes of toxic elements through ground- and surface-waters [Delmelle and Bernard, 2000; Varekamp et al., 2009]. The study area of this paper, Nisyros, is a currently active volcanic area. The geothermal field of Nisyros has been characterized as the hottest and most dynamic field in Greece, due to the presence of magma chamber at shallow depths. The high geothermal anomaly of Nisyros is manifested at surface by the occurrence of hot springs and fumaroles [Marini and Fiebig, 2005]. The major fumarolic vents are located in the craters of Kaminakia, Mikros Polyvotes, Megalos Polyvotes and Stefanos [Caliro et al., 2005]. In this article, the results of mineralogical and chemical analyses of soil samples collected in the caldera of Nisyros Island are presented. This dataset summarizes the results of field observations and experimental measurements, regarding the distribution of trace element concentrations related to the contribution of fluids of deep origin.

\section{STUDY AREA}

Nisyros is the easternmost island of the South Aegean Active Volcanic arc in Greece.
It is an active stratovolcano, mainly consisting of Quaternary volcanic rocks and alternations of lava flows, pyroclastic deposits and lava domes. The island has an area of $47 \mathrm{~km}^{2}$ and forms a truncated cone with a base diameter of $8 \mathrm{~km}$ and a $4 \mathrm{~km}$ wide central caldera [Hunziker and Marini, 2005]. The northern part of the caldera is named Lakki Plain and the southern Ramos Plain. No historical magmatic activity is known on Nisyros and the most recent activity was of hydrothermal character [Marini et al. 1993]. Fumarolic emissions are located in the southern Lakki Plain and on the southeastern flank of the Lofos dome both within the caldera. Hydrothermal eruptions formed a series of hydrothermal explosion craters whose ages decrease from southeast to northwest. The last phreatic eruptions took place in 1871-1873 and 1887 partially destroying the small Lofos dome. Two deep explorative geothermal wells drilled in the Lakki plain revealed the existence of two distinct hydrothermal aquifers. The shallowest at about $500 \mathrm{~m}$ depth has temperatures around $150{ }^{\circ} \mathrm{C}$ while the deeper one $(>1500 \mathrm{~m})$ reaches temperatures up to 340 ${ }^{\circ} \mathrm{C}$ [Brombach et al., 2003].

\section{MAterials And Methods}

On June 2013, 33 samples of top-soils were collected in the caldera area (16 within the Stefanos Crater and 17 in the Lakki Plain at different distance from the fumarolic areas). All samples were collected in areas covered either by reworked volcanic material (mainly deriving from the Prophitis Ilias post-caldera lava domes) or by the products of the most recent (1871-1887 $\quad$ A.D.) hydrothermal explosion activities (Annex 1). Moreover, 1 soil sample was collected outside the caldera as local background, for comparison. In the laboratory, all soil samples were dried at temperatures below $36^{\circ} \mathrm{C}$ and powdered in an 
agate mortar. Then, the powder was divided in 3 aliquots for the following analysis (XRD, Leaching and Microwave Digestion). Detailed description of the analytical methods can be found in the electronic annex (Annex 2).

\section{Results And Discussion}

Soil acidity: $\mathrm{pH}$ is one of the most important parameters that influences soil alteration and, consequently, the geochemical mobility of elements. The values measured in the sampled soils display a wide range (from 1.9 to 7.2), with lower values found where the fumarolic activity is more intense. The good inverse correlation between $\mathrm{S}$ concentration and $\mathrm{pH}$ (Fig. 1) is related to $\mathrm{H}_{2} \mathrm{~S}$ degassing. $\mathrm{H}_{2} \mathrm{~S}$, one of the main components of the fumarolic gases at Nisyros [Marini and Fiebig, 2005], in the shallow oxidizing environment produces $\mathrm{H}_{2} \mathrm{SO}_{4}$. Basing on $\mathrm{pH}$ values, it is possible to distinguish the soils in two main groups and a reference value: i) the soils of the active fumarolic field of Stefanos Crater (1.9 - 3.4), ii) the soils from the Lakki Plain $(4.2-5.8)$ and iii) the reference value of the background soil (7.2) (Fig. 1). The results obtained from the XRD analysis showed that in the majority of the Lakki Plain soils the main mineralogical assemblage is Quartz, Feldspar and Gismondine $\left(\mathrm{Ca}_{2} \mathrm{Al}_{4} \mathrm{Si}_{4} \mathrm{O}_{16} \bullet 9 \mathrm{H}_{2} \mathrm{O}\right)$.

Mineralogical composition: The latter is a Zeolite that derives from the hydrothermal alteration of Plagioclase. In some samples, Stellerite $\left(\mathrm{CaAl}_{2} \mathrm{Si}_{7} \mathrm{O}_{18} \cdot 7 \mathrm{H}_{2} \mathrm{O}\right)$ is appearing as a result of hydrothermal alteration, whilst Wollastonite $\left(\mathrm{CaSiO}_{3}\right)$ is also found as a product of thermally metamorphosed siliceous carbonates. In the crater soils, because of the low $\mathrm{pH}$ values (1.9-3.8) and the relatively high temperatures of the fumaroles (about $100^{\circ} \mathrm{C}$ ), the main assemblages mostly comprises hydrothermal alteration minerals. Quartz, Sulfur, Wollastonite, Gypsum and Gismondine were found in most of the samples.

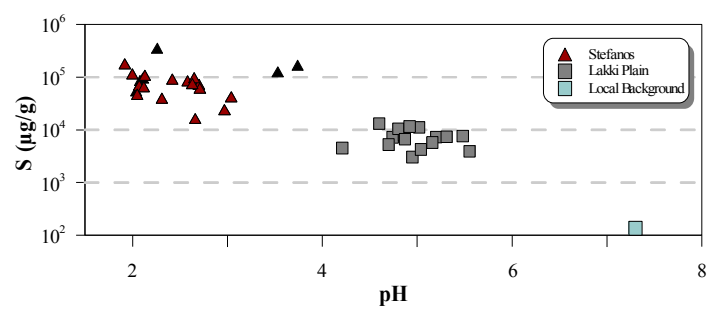

Figure 1: $p H$ vs. $S$ in soils binary plot.

The lower amount of Feldspars with respect to the Lakki Plain soils can be justified by the high percentage of Gismondine, their alteration products. Voltaite $\left(\mathrm{K}_{2} \mathrm{Fe}(\mathrm{II})_{5} \mathrm{Fe}(\mathrm{III})_{3} \mathrm{Al}\left(\mathrm{SO}_{4}\right)_{12} \bullet 18 \mathrm{H}_{2} \mathrm{O}\right)$ was also found in some of the samples as a product of hydrothermal alteration of $\mathrm{Si}$ deposits. Close to the fumaroles, the occurrence of Alunogen $\left(\mathrm{Al}_{2}\left(\mathrm{SO}_{4}\right)_{3} \cdot 17 \mathrm{H}_{2} \mathrm{O}\right)$, a sulphide alteration mineral found in fumarolic environments, is also noticeable. The mineralogical assemblages in the caldera of Nisyros are presented in Annex 3.

Geochemical mobility of major and trace elements: The results of the analysed major and trace elements are reported in box and whisker plots (Fig. 2) and in the tables of Annex 3. The data obtained from leaching and microwave digestion were both sorted according to the median value of the pseudo-total composition of the soils. Furthermore, the local background was added in the graphs and presented as black dash lines, in order to allow a comparison. The concentration of local background shows sometimes values differing up to two orders of magnitude with respect to the soils of Stefanos Crater and Lakki Plain (Fig. 2a). These differences are caused by the hydrothermal activity that is or has been present in the Lakki Plain area. Some of major and trace elements display strong enrichments. 
ANNALS OF GEOPHYSICS, Fast Track 2, 2014

Most of these elements are highly volatile ( $S$, As, Se, Bi, Sb, Tl and Te). On the contrary, a few elements show strong depletions in the Stefanos and Lakki Plain soils with respect to the background soil ( $\mathrm{Ca}, \mathrm{Mg}, \mathrm{Ti}, \mathrm{Mn}, \mathrm{Ni}$ and Li). These elements have high solubility, thus they were likely- leached out of the soils. This could be related to the low to very low $\mathrm{pH}$ values, which enhance their mobility. The most soluble elements, such as $\mathrm{Ca}, \mathrm{Mn}, \mathrm{Zn}, \mathrm{Ni}$, Li, $\mathrm{Be}, \mathrm{Cd}$, are highlighted in Figure $2 \mathrm{c}$ where the

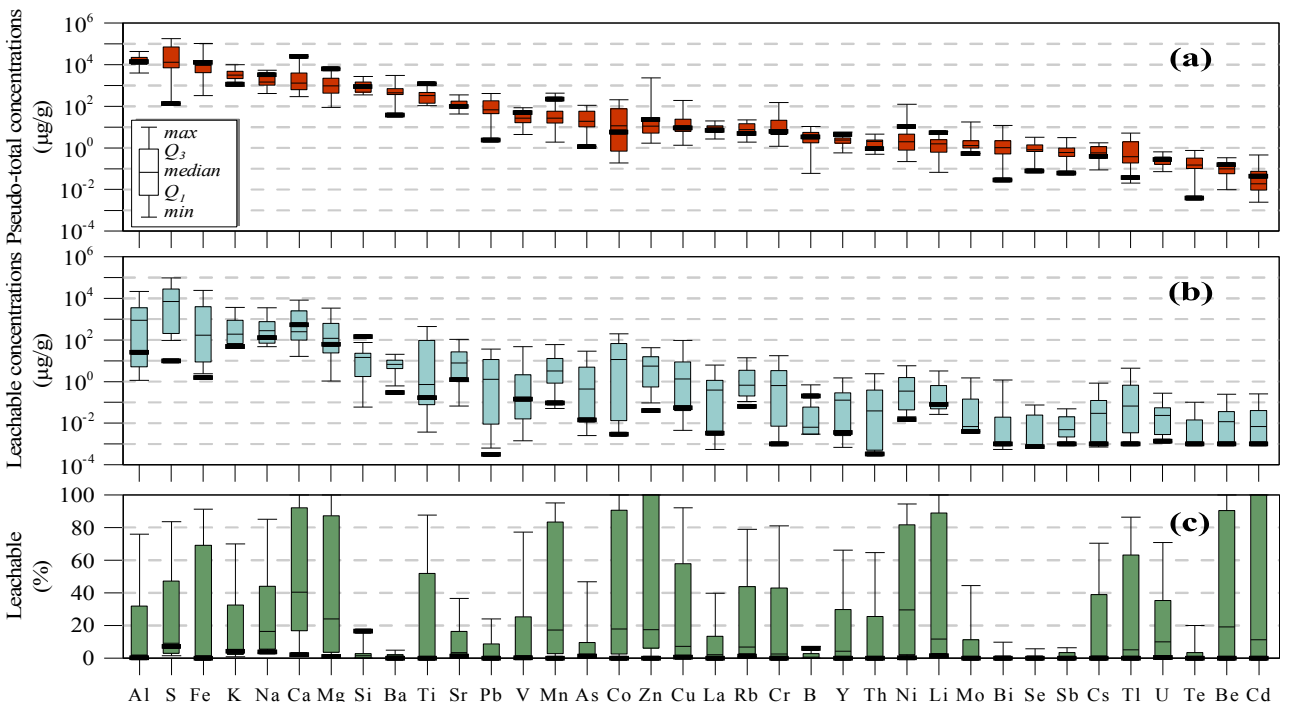

Figure 2: Box and whisker plots of (a) pseudo-total concentration, (b) leachable concentration and (c) solubility (\% of leachable with respect to pseudo-total content). The black dash lines are the values of local background. The elements are ordered basing on decreasing median pseudo-total concentrations.

percentages of the leachable element with respect to the pseudo-total concentration of the same element are shown (Fig. 2).

The enrichment factor (EF) is a useful tool to show the enrichment or depletion degree of a given element in a geochemical medium relative to a reference material and has been used in this study in order to distinguish elements with different geochemical mobility. The enrichment factor of an element $x$ can be calculated as:

$$
\mathrm{EFx}=(\mathrm{Cx} / \mathrm{Cr})_{\text {sample }} /(\mathrm{Cx} / \mathrm{Cr})_{\mathrm{rm}}
$$

where $(\mathrm{Cx} / \mathrm{Cr})_{\text {sample }}$ is the concentrations ratio of an element $x$ normalized to a reference element $(\mathrm{r})$ in the sample and $(\mathrm{Cx} / \mathrm{Cr})_{\mathrm{rm}}$ is the corresponding ratio in a reference material (rm). The results obtained (Annex 1), highlight enrichments or depletions with respect to the "normal" soils of the island and therefore we used the background soil samples as reference material. Th being characterized by a scarce mobility was chosen as reference element (r).

Basing on the calculated EFs, the elements analysed in the soils of Nisyros can be subdivided in 3 groups:

Group A: enriched elements, e.g. S, Tl, Bi, Pb, $\mathrm{Te}, \mathrm{Sb}, \mathrm{Se}, \mathrm{As}, \mathrm{Ba}$; (EFs > 10)

Group B: slightly enriched to slightly depleted elements, e.g. La, Sc, Be, Al, Ti, V, Zn, Y, U, $\mathrm{Sn}, \mathrm{Mo}, \mathrm{K} ;(10>\mathrm{EFs}>0.1)$

Group C: depleted elements e.g. Fe, Mn, Mg, $\mathrm{Cd}, \mathrm{Ca}, \mathrm{Na}, \mathrm{B}, \mathrm{Li}(\mathrm{EFs}<0.1)$.

The geochemical behaviour (enrichment or depletion) of the elements mainly depends on their mobility. The relative mobility within the soils is mainly controlled by their water 
solubility that can be, in the present case, estimated from leachable \% shown in Fig. 2. The most depleted elements (Group C) have
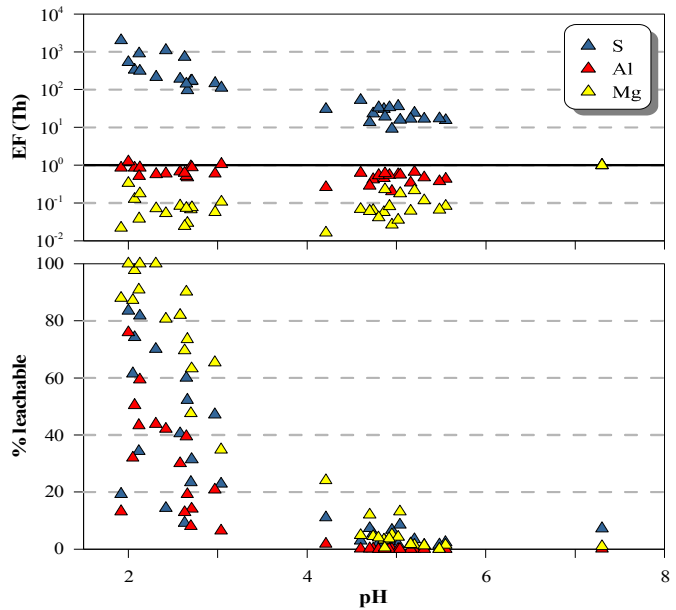

generally higher solubility especially in the most acidic soils and are easily leached out leaving the soils depleted.

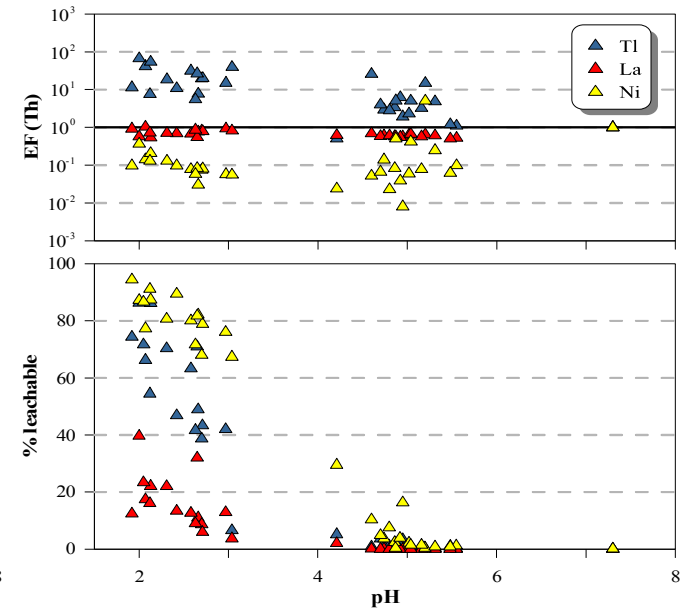

Figure 3: Graphs of the EFs of the major (a) and trace (b) elements normalized with respect to the immobile element Th and their relative mobility gained from their leachability $(c$ and $d)$.

The elements of Group B have intermediate solubility and tend to remain in the soils, whereas that of Group A show a relatively low solubility and, consequently, accumulate in the soils. Due to the fact that the mobility of the elements strongly depends on the soil $\mathrm{pH}$, the highest enrichments or depletions are therefore found close to the most active fumarolic area of Stefanos where the soils reach the lowest $\mathrm{pH}$ (Fig. 3). Most of the elements of Group A are highly volatile. Fulignati et al. [2006] found the same elements strongly enriched in the rock coatings of the fumarolic area at Vulcano island in Italy. But while in that case fumarolic temperatures up to nearly $700{ }^{\circ} \mathrm{C}$ could justify a gaseous transport of these elements, in the present case, lower fumarolic temperatures (< $100{ }^{\circ} \mathrm{C}$ ) make such transport less probable, although some of these elements could be present as gases $\left(\mathrm{H}_{2} \mathrm{Se}, \mathrm{H}_{2} \mathrm{Te}\right.$ and $\left.\mathrm{AsH}_{3}\right)$. Further gaseous species of As (Planer-Friedrich et al., 2006) and other metals (Ti, V, Mo, W, Ni, $\mathrm{Cu}, \mathrm{Zn}, \mathrm{Cd}, \mathrm{Ga}, \mathrm{Si}, \mathrm{Ge}, \mathrm{Pb}$ and $\mathrm{Sb}$ - Planer-
Friedrich and Merkel, 2006) have also been identified at low temperature hydrothermal features at Yellowstone (U.S.A.). At Nisyros enrichment of some element $(\mathrm{Ba}, \mathrm{Pb}, \mathrm{As}, \mathrm{Se}, \mathrm{Bi}$, $\mathrm{Tl}, \mathrm{Sb}$ and $\mathrm{Te}$ ) with respect to the background soil could be also due to the fact that most of the soils in Lakki plain and the Stefanos crater area derive from the explosive activity of the XIX century. Such activity deposited hot and hypersaline muds deriving from the deep hydrothermal system enriched in these elements. Furthermore the highest $S$ contents, mainly in the form of sulphate, contribute to the accumulation in these areas of the elements that form highly insoluble sulphate minerals (e.g. $\mathrm{Pb}, \mathrm{Ba}$ etc.) especially where $\mathrm{H}_{2} \mathrm{~S}$ is continuously supplied by fumarolic activity.

\section{CONCLUSIONS}

The island of Nisyros is characterized by a wide fumarolic field inside the Lakki Plain. The soils of Stefanos, one of the main active 
ANNALS OF GEOPHYSICS, Fast Track 2, 2014

craters of the Lakki Plain caldera, showed low $\mathrm{pH}$ values, high concentrations of $S$ and anomalous temperatures that reach the boiling point of water. Due to these conditions, the main assemblage mostly comprises hydrothermal alteration minerals. Quartz, Sulfur, Wollastonite, Gypsum, Alunogen and Gismondine are found in most samples from Stefanos crater, whereas in the soils of Lakki Plain, where the conditions are not so acidic, primary minerals are more abundant. The geochemical behaviour of the investigated elements depends mainly on their mobility, which in turn mainly depends on soil $\mathrm{pH}$ and therefore from distance of the soils from the main fumarolic emissions. The most soluble elements were $\mathrm{Fe}, \mathrm{Mn}, \mathrm{Mg}, \mathrm{Cd}, \mathrm{Ca}, \mathrm{Na}, \mathrm{B}$ and Li. The high solubility contributes in leaching out the elements and leaving the soil depleted, while elements with low solubility tend to accumulate in the soils.

\section{REFERENCES}

[Alpers et al., 2000] Alpers, C.N., Jambor, J.L., Nordstrom, D.K. eds., (2000). Sulfate Minerals -Crystallography, Geoch. and Environment Significance. Rev. Min. Geochem. 40, 608pp.

[Brombach et al., 2003] Brombach, T. Caliro, S., et al. (2003). Geochemical evidence for mixing of magmatic fluids with seawater, Nisyros hydrothermal system, Greece. Bull. Volcanol., 65(7), 505-516.

[Caliro et al., 2005] Caliro, S. Chiodini, G., et al. (2005). Recent activity of Nisyros volcano (Greece) inferred from structural, geochemical and seismological data. B. Vol., 67(4), 358-369.

[Delmelle and Bernard, 2000] Delmelle, P., Bernard, A. (2000). Downstream composition changes of acidic volcanic waters discharged into Banyupahit stream, Ijen caldera. J. Volcanol. Geotherm. Res., 97, 55-75.

[Fulignati et al., 2006] Fulignati, P., Sbrana, A., et al. (2006). Environmental impact of the acid fumarolic plume of a passively degassing volcano (Vulcano island, Italy). Environ. Geol., 49, 1139-1155.

[Hunziker and Marini 2005] Hunziker, J.C., Marini, L. (eds.) (2005). The geology, geochemistry and evolution of Nisyros volcano. Implications for the volcanic hazard. Memoires Geologie (Lausanne) n. 44.

[Jambor et al., 2000] Jambor, J.L., Nordstrom, D.K., et al. (2000). Metal-sulfate salts from sulfide mineral oxidation. In: Sulfate Minerals -Crystallography, Geochemistry and Environmental Significance. Rev. Min. Geochem., 40, 303-350.

[Marini and Fiebig, 2005] Marini, L., Fiebig, J. (2005). Fluid geochemistry of the magmatichydrothermal system of Nisyros (Greece). Memoires Geol. (Lausanne) n. 44, 121-163.

[Marini et al., 1993] Marini, L., Principe, C., et al. (1993). Hydrothermal eruptions of Nisyros (Dodecanese, Greece). Past events and present hazard. J. Volcanol. Geotherm. Res., 56, 71-95.

[Nordstrom et al., 2009] Nordstrom, D.K., McCleskey R.B., Ball, J.W. (2009). Sulfur geochemistry of hydrothermal waters in Yellowstone National Park: IV acid-sulfate waters. Appl. Geochem., 24, 191-207.

[Planer-Friedrich and Merkel, 2006] PlanerFriedrich, B., Merkel, B. (2006). Volatile metals and metalloids in hydrothermal gases. Environ. Sci. Technol. 40, 3181-3187.

[Planer-Friedrich et al., 2006] Planer-Friedrich, B., Lehr, C., et al. (2006). Speciation of volatile arsenic at geothermal features in Yellowstone National Park. Geo. Cos. Acta 70, 2480-2491.

[Robinson et al., 2005] Robinson, B., Bolan, N., et al. (2005). Bioaccumulation of Trace Elements: Abiotic Processes in the Rhizosphere. Trace El. in the Environ., 93-106. [Varekamp et al., 2009] Varekamp, J.C., Ouimette, A.P. et al., (2009). Naturally acid waters from Copahue volcano, Argentina. Appl. Geochem., 24, 208-220. 